\title{
Creating Social Change in and Through Intercollegiate Sport
}

\author{
E. Nicole Melton \\ University of Massachusetts-Amherst
}

\begin{abstract}
The purpose of this paper is to introduce the work included in the special issue: Creating Social Change in and Through Intercollegiate Sport. In doing so, the author develops a multilevel conceptual model, demonstrating how the research included in the special issue addresses the antecedents and outcomes of social change initiatives in intercollegiate sport at the macro (i.e., institutionalized practices, cultural norms), meso (i.e., support of others, compelling narratives, collaborations) and microlevel (i.e., perspective-altering experiences, attitudes toward role of sport) of analysis. In addition, the author suggests ways to overcome barriers and increase the success of future social change initiatives. Based on this collection of scholarship, the author encourages researchers and practitioners to consider the multilevel factors that influence social change and the subsequent outcomes of such actions.
\end{abstract}

In August 2005, the National Collegiate Athletic Association (NCAA) faced fierce criticism when it adopted a policy prohibiting NCAA institutions from displaying Native American mascots, nicknames, or imagery during NCAA-sponsored events. Those that chose to continue using the imagery would be ineligible to host NCAA championships starting in 2006. Former NCAA president Myles Brand was resolute in his response to critics who said the NCAA should focus on athletic matters and stay out of social issues. He noted how intercollegiate athletics is deeply ingrained within American society, and given the interest and attention it commands, "we should not underestimate the potential of athletics to contribute to social change, nor should we shy away from that responsibility" (Brand, 2005, p.1).

Since Brand's call to action, a number of individuals and entities within intercollegiate sport have demonstrated a commitment to social change. This past year, for instance, the NCAA and several conferences joined the national "It's On Us" initiative, which seeks to end sexual assault on college campuses (Jackson, 2015). The campaign urges students to stop being passive bystanders in the problem of sexual assault, and to start playing an active part in the solution. In addition to conference led initiatives, there are also examples of athlete-initiated support for social change. One of the most memorable examples occurred when Notre Dame women's basketball players wore "I Can't Breathe" shirts during a pregame warmup

Melton is with the McCormack Department of Sport Management, Isenberg School of Management, University of Massachusetts-Amherst, Amherst, Massachusetts. Address author correspondence to Nicole Melton at nmelton@isenberg.umass.edu. 
to support the family of Eric Garner-an unarmed Black man who died after a police officer placed him in a chokehold while trying to arrest him (ESPN, 2015). The phrase had become a rally cry for those around the country working to raise awareness, continue the debate, and demand an end to racial injustices. While the previous examples highlight how the visibility of sport can increase public awareness of societal issues, there is also evidence of change within intercollegiate sport. At Duke University, varsity teams furthered the \#YouDon'tSay movement using social media to combat negative language that demeans those with marginalized identities in sport. Members of the women's soccer team, for instance, posted a team photo with the caption, "We don't say 'kick like a girl' because it trivializes all that women have accomplished in sports" (Maine, 2015).

While the aforementioned examples are certainly encouraging and illustrate how sport can promote prosocial attitudes and behaviors, there is much work to do. Indeed, research exploring various sport settings consistently shows instances of social injustice are commonplace in college sport and negatively affect athletes, coaches, administrators and staff. A review of this literature suggests most investigations have focused on the prevalence and destructive effects of injustices related to race (Agyemang, Singer, \& DeLorme, 2010; Cunningham, 2010; Singer, 2005), gender (Bruening \& Dixon, 2008; Burton, 2014; Cunningham, 2008; Fink, 2014; Shaw \& Frisby, 2006) sexual orientation (Cunningham, 2012; Melton \& Cunningham, 2012, 2014; Sartore and Cunningham, 2010), physical ability (Misener \& Darcy, 2014), unethical leadership practices (Burton \& Welty Peachey, 2014), and athlete rights (Staurowsky, 2014). Interestingly though, theoretical and empirical examinations of how intercollegiate sport - as an institution and the individuals associated with it - promotes social change have lagged behind considerably.

The lack of systematic investigations on this topic is unfortunate for several reasons. First, sport leaders often have greater levels of cultural power, credibility, and trust within society (Burnett, 2006), which allows them to be effective advocates for social change (Edwards, 2015). Second, sport-for-development research illustrates how organized sport is a powerful mechanism to affect social change; however, most of this work is situated outside the intercollegiate sport context. Third, championing social change and inclusion efforts within an athletic department relates to increased well-being and organizational commitment at the individual level (Walker \& Melton, in press), and improved creativity and performance at the organizational level (Cunningham 2011a, 2011b). Finally, anecdotal evidence and extant research in sport has offered contradictory results. Both the NCAA and its member institutions have expressed an increased commitment to empower socially responsible athletes (NCAA, 2007) and have encouraged advocacy behaviors (ESPN, 2015). However, there continues to be instances where athletes are inhibited from advocating for their rights (Staurowsky, 2014), and a number of athletic departments fail to provide opportunities for civic engagement (Andrassy \& Bruening, 2011). Considering the potential of sport to create change, and benefits for doing so, there is a need for more critical, systematic examinations of social change in the intercollegiate sport context to fully understand these issues.

Therefore, in addressing this need, the purpose of this special issue is to advance theory and research on social change in and through intercollegiate sport. The papers included here accomplish this objective. Specifically, the authors demonstrate that participating in sport-based service learning courses can empower and motivate 
students to work toward social justice in their communities (Fuller et al., 2015); describe how displaying small acts of inclusion and respect can challenge gendered norms in intercollegiate sport (Taylor, 2015); develop a conceptual model for how athletic departments can be agents of change (Cunningham, 2015); show how community-based social marketing plays a vital role in promoting proenvironmental behaviors at sporting events (Martin, Ross, \& Irwin, 2015); explore how academic and industry partnerships provide opportunities for social change in women's sport (Walker \& Melton, 2015); and outline challenges and opportunities for future research (Welty Peachey, 2015). In the following space, I diverge from the traditional introduction to the special issue format and instead, present the work within a broader, multilevel conceptual framework. Doing so recognizes the multilevel nature of sport organizations (Kozlowski and Klein 2000) and allows for a discussion of how the papers included in the special issue relate to one another.

\section{Social Change Defined}

In the broadest sense, social change is any alteration in social relations or structures, which is generally characterized by changes in cultural norms, symbols, patterns of behaviors, social organizations, or value systems. While individuals adopt some social changes rather quickly (e.g., using social media to consume spectators sports), other changes-particularly ones that disrupt the status quo or distributions of power-can be more difficult to accept. For instance, people often resist change that seeks to improve the position of marginalized groups by minimizing social or structural inequalities. In addition, social change can be intentional or unplanned. When Michael Jordan wore longer and roomier shorts, for example, he did not intend to drastically alter basketball fashion. Tommie Smith and John Carlos, on the other hand, purposefully bowed their heads and raised a black-glove-covered fist on the Olympic podium to represent black power and black unity in a racially unjust America. In this special issue, the work focuses on the more deliberate efforts made by individuals or athletic departments to create meaningful social change in, and through, intercollegiate sport (conceptualized as a social institution).

\section{Multilevel Model of Social Change in Intercollegiate Sport}

It is important to recognize that sport organizations (i.e., intercollegiate athletic departments) are multilevel entities, in that activities and practices operating at one level of analysis have the potential to influence those operating at other levels. For instance, Melton and Cunningham (2014) observed that sport employees were more likely to advocate for LGBT equality if they witnessed coworker and leader support for inclusion (factors that operate at the organizational level of analysis), and had personal contact with sexual minorities (individual level factor). After experiencing support within the athletic department, LGBT sport employees felt more included and were more likely to disclose their sexual orientation to others (individual level outcomes). In the current paper, I draw from the scholarly works in this social issue to develop a model that illustrates the antecedents and outcomes 


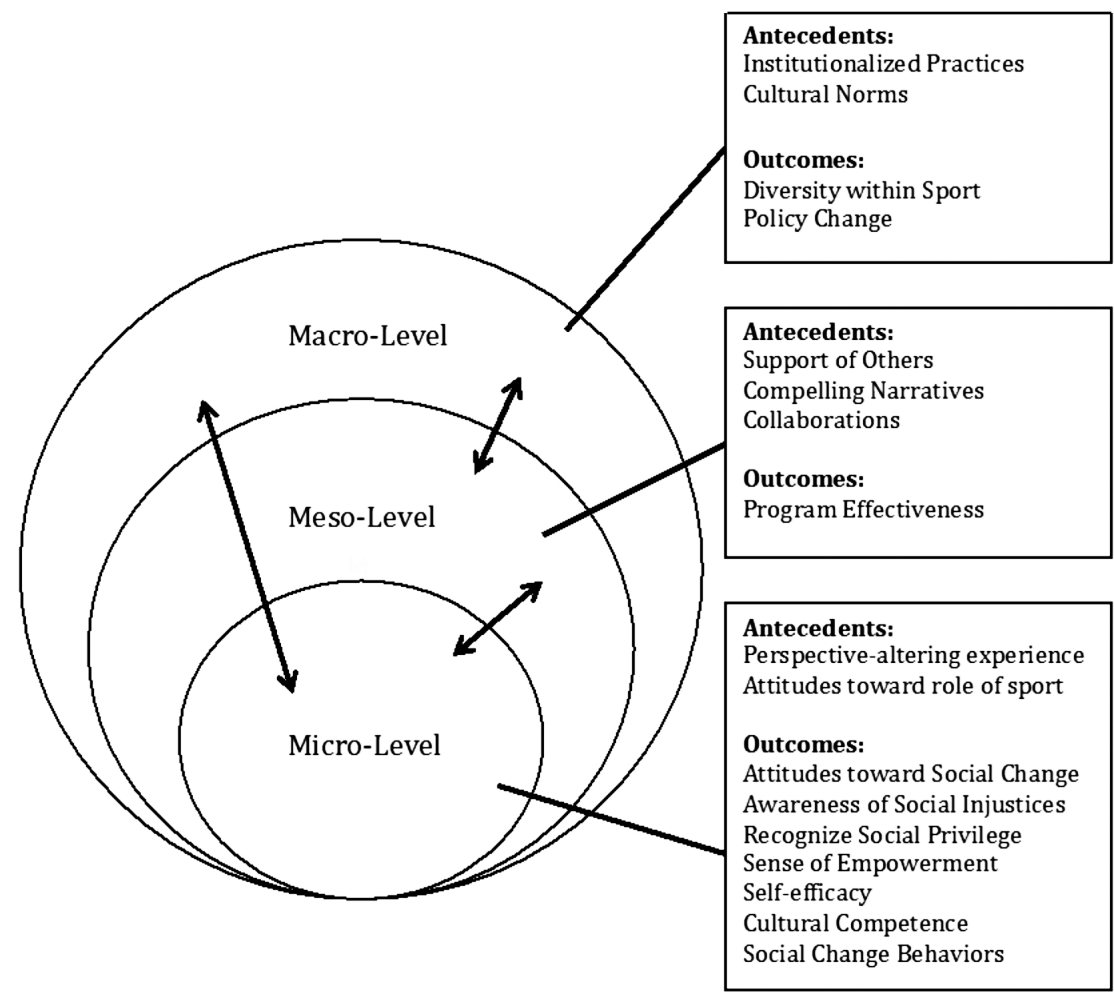

Figure 1 - Multilevel Model of Social Change in Intercollegiate Sport

of social change in intercollegiate sport operating at the macro-level (i.e., societal), meso-level (organizational or group influences), and microlevel (see Figure 1).

\section{Macro-Level Factors}

Macro-level factors manifest at the societal or industry level of analysis. The articles in this special issue point to two macro-level factors: institutionalized practices and cultural norms.

Institutionalized Practices. Institutionalized practices represent the norms and social practices within a particular industry that become so entrenched in social thought and actions that they take on rule-like status (Meyer \& Rowan, 1977). Further, as people habitually repeat these activities, mindsets, and ideals over time, they begin to automatically accept them and defend the legitimacy of doing so (Washington \& Patterson, 2011). Several sport management scholars have argued that because of the tradition, leader behaviors, and prevailing stereotypes, gender discrimination has become institutionalized in sport (Burton, 2014; Cunningham, 2008; Walker \& Sartore-Baldwin, 2013). 
In this special issue, Taylor (2015), Walker and Melton (2015), and Cunningham (2015) emphasize the influence of institutionalized practices on social change in intercollegiate sport. Taylor (2015) described his personal journey as an athlete, coach, and advocate to illustrate the challenges and opportunities associated with supporting inclusion for lesbian, gay, bisexual, and transgender individuals within intercollegiate sport. He notes that for male athletes,

"femininity is the anti-thesis of the athlete archetype. Homophobic and sexist slurs, stories of opposite sex attraction, and the discouragement of nonmasculine interests or attire are often central to locker room banter. In this way, male athletes pressure one another to conform to an orthodox concept of masculinity...(p.39).

Those who conform to the athlete archetype are rewarded, while those who challenge the norm face ridicule and often decide (voluntarily or reluctantly) to leave intercollegiate sport. Walker and Melton (2015) also observed that institutionalized practices within sport media discourage journalists from focusing on women's sport because they receive greater rewards for covering men's sport. Consequently, the most talented employees prefer to work in men's sport organizations. In his theoretical paper, Cunningham (2015) argues LGBT-inclusive athletic departments, a rarity within intercollegiate sport, may provide a way to reinstitutionalize industry practices. Specifically, by modeling inclusive behaviors and effectively articulating the moral and business case for inclusion, these athletic departments will motivate others to follow their example.

Cultural Norms. Cultural norms represent "a shared expectation that people use to identify what is acceptable and unacceptable in a social world" (Coakley, 2009, p. 157). They provide a blueprint for understanding what attitudes and behaviors are acceptable in a certain context, and they have the potential to shape how people view social change initiatives in intercollegiate sport. Consider, for instance, that findings from large-scale survey research indicates that Americans are now more aware of environmental issues and are making lifestyle changes that make a positive environmental impact. When comparing current survey results to data from 20 years ago, twice as many people recycle, purchase environmentally friendly products, and limit the use of personal automobiles when commuting to work. The growing national consensus that people should adopt "green" behaviors has led Americans to believe companies should also assume a leadership role in protecting the environment. This is perhaps why we have seen an increasing number of corporations adopt green initiatives, including professional sport organizations. Martin, Ross, and Irwin (2015) suggest this is a reason why more college athletic departments are creating programs to encourage proenvironmental behaviors among fans. Findings from Martin et al. (2015) suggest that when these programs are implemented in the college sport setting, behavioral change can happen at the community level.

Finally, the papers in this special issue point to how social change (or lack thereof) can influence the sport industry and society in general. Taylor (2015), for instance, discussed how athlete archetypes discourage people from advocating for social change; compel them to conceal their unique identities; and at times, choose to leave college sport. Walker and Melton (2015) also observed how reward structures 
in the sport media industry discourage journalists from covering women's sport, thereby perpetuating the notion that men's sport is more important. However, there are instances when collective action within sport influences the broader society. Taylor (2015), for example, described how Athlete Ally partnered with Lambda Legal to launch the \#Final4Fairness campaign during the NCAA Men's Final Four Championship in Indianapolis. The campaign provided athletes, coaches, and fans a way to publically express their opposition to an anti-LGBT legislation in Indiana, and in doing so, raised national awareness about the discriminatory effects of the law. The collective outcry from citizens, local and national business, the NCAA, and notable sport figures ultimately led to the Indiana governor amending the law. Thus, while collective action within sport can inspire societal level change, sociallyminded people in sport may feel forced to conform to institutionalized norms or choose to leave intercollegiate sport.

\section{Meso-Level Factors}

In addition to macro-level factors, meso-level factors can also influence social change in intercollegiate sport. These factors operate at the organizational, group, or dyadic level of analysis and include support of others, compelling narratives, and collaborations.

Support of Others. Support from relevant others (e.g., leaders, teammates, coworkers, family and friends) has a considerable effect, both positive and negative, on promoting social change within intercollege sport. The attitudes, behaviors, and policies they support establish a model for others to follow. Bandura (1986), in presenting his social learning theory, noted, "virtually all learning phenomena, resulting from direct experience, can occur vicariously by observing other people's behaviors and the consequences for them" (p. 19). Thus, when a leader or teammate expresses explicit or implicit support for social change initiatives, it is likely that others will as well; on the other hand, ambivalence or opposition toward a social change will also be mirrored.

The effect of support from others was evident is this special issue, particularly in Walker and Melton's (2015) interview with Kate Fagan. During the interview, Kate described how the editors, writers, and producers at espnW constantly search for interesting stories within women's sport. In this environment, journalists feel empowered to explore, and write about, a variety of issues facing female athletes. However, the support for these issues seems to fade when Kate crosses over to ESPN, as there is more pressure (implicit and explicit) to adhere to traditional sport stories focusing on men's sport. Fuller et al.'s (2015) examination of a sport-based service learning course also points to how the actions of relevant others can encourage social change. First, the faculty members clearly established their support for social justice through their course design. They developed a service-learning course with a change-oriented emphasis on activism, which is unique in sport management programs (see Cunningham, 2014). They set learning objectives related to social justice behaviors; provided students with the resources and opportunity to engage in a social change initiative, and encouraged critical reflection during the course. These collective actions set a clear message that the instructors valued social justice behaviors. 
Papers in the special issue also note the influence of peers on social change. Specifically, in their study examining the impact of a community-based social marking intervention on recycling behaviors among college football fans, Martin and his colleagues (2015) observed that tailgaters were more receptive to recycling educators who were from their peer group. In addition, in their study on the influence of a sport-based service learning course, Fuller et al. (2015) observed how peers provided needed support when some students experienced negative feedback after advocating for social justice. Peer support may be particularly relevant in the intercollegiate sport context, as Taylor (2015) noted how persistent nonsupportive actions displayed by teammates led many athletes to conform to noninclusive athlete archetypes. Findings from other investigations within intercollegiate sport settings also demonstrate the importance of peer support in encouraging social change (Melton \& Cunningham, 2014).

Compelling Narratives. Compelling narratives represent another meso-level factor affecting social change in intercollegiate sport. Both scholars and practitioners recognize the difficulty in inspiring prosocial behavioral, but suggest communication strategy and tactics can play a vital part in building support for social change initiatives (Hayles, 2014; Hayles \& Russell, 1997). Cunningham's (2015) theoretical paper touched on the role of organizational communication, and suggested organizations use two types of messages when garnering support for LGBT inclusion. First, he argued athletic departments should present moral legitimacy arguments when advocating for inclusion, but cautioned that relying solely on such positions would not effectively motivate everyone to change their behavior. To gather support from a broader audience, sport organizations need to also articulate how inclusive environments relate to improved individual and organizational performance. The community-based social marketing literature supports the notion that communication messages must resonate with the target population (see Martin et al., 2015), and notes that the communication tool needs to be memorable, personally relevant, focused, and conveyed by a trusted source.

Walker and Melton's (2015) interview with Kate Fagan also demonstrates the power of compelling narratives. Fagan contends simply televising more women's sporting events does little to alter traditional perceptions of women's sport. While increased coverage signals the legitimacy of these sports, it does not provide a meaningful way for fans to connect with female athletes. To bridge the disconnect and increase public interest, Fagan uses intriguing storytelling as a way for fans to learn more about the athletes, become invested in their progress, and understand the importance of their accomplishments. While interesting stories help Fagan increase awareness of and interest in women's sport, Taylor (2015) suggests the stories of straight allies offer a counter-narrative to prevailing norms in sport that discourage acts of LGBT inclusion. Such accounts outline how change is possible and provide a blueprint for others to follow. Collectively, the works presented in this special issue point to how compelling narratives can change perceptions at the macro-level of analysis (e.g., improve public perceptions of women's sport), and also inspire behavioral change at the individual level.

Collaborations. According to Gray (1989), collaboration is "a process through which parties who see different aspects of a problem [or issue] can constructively explore their differences and search for solutions that go beyond their own limited 
vision of what is possible" (p. 5). When diverse entities work together, rather than alone, they draw on their combined strengths to create meaningful change in society. It is important to note that collaborations focus on relationships, meaning partners work together, not just alongside one other to solve problems or issues. In addition, in order for a partnership or collaboration to be successful, all parties must have clear and mutually understood objectives, maintain realistic expectations of what they can achieve, and work toward meeting the interests of each party (Hudson, 2009).

In this special issue, authors demonstrate the importance of collaborations and partnerships in creating change in and through intercollegiate sport. For example, Fuller et al.'s (2015) study on the impact of a sport-based service learning course, suggests partnering with academic courses is an effective way for athletic departments to achieve their service-oriented goals. In addition, Martin et al. (2015) shows how a partnership between the athletic department, sport management program, and student groups enhanced the effectiveness of a community-based change imitative promoting proenvironment behaviors among college football fans. Specifically, using recycling educators from a variety of campus groups helped the campaign connect with a wide array of student fans and achieve desired goals.

Walker and Melton's (2015) interview with Kate Fagan highlights how collaborations between researchers and practitioners benefit both parties. For instance, most sport management researchers seek to make a practical impact on the field; therefore, disseminating one's research to a broad, nonacademic audience achieves this end. From an industry perspective, Fagan explained that empirical findings resonate with readers and make her articles on women's sport more interesting. It is important to note, however, that empirical data must be relevant to practitioners. Thus, establishing partnerships with industry professionals helps researchers discover and answer practical questions. These observations support Fink's (2014) assertion that collaborative efforts between academia and industry are a necessary way to create change in women's sport.

\section{Micro-Level Factors}

Microlevel factors operate at the individual level of analysis and help explain why certain individuals may be more likely to engage in social change initiatives in sport. In drawing from the work in this special issue, I focus on two microlevel factors here: perspective-altering experiences and attitudes toward the role of sport.

Perspective-Altering Experiences. Research in various fields has identified a number of individual level factors that influence one's attitudes and behaviors related to social change, including demographic variables, personality characteristics, and contact with members of marginalized groups. There is less understanding though, on how to instill the importance of social change in individuals who have not encountered or are not aware of social injustices. However, Fuller et al. (2015) provides evidence that participating in perspective-altering experiences, such as a sport-based service learning class, can improve attitudes and increase behaviors related to social justice for all persons-irrespective of one's social status or past experiences. Importantly, the success of the perspective-altering experience is dependent on key factors. First, individuals must understand the historical and social 
issues related to social injustice. The in-class course work in the sport-based service course provided this education. Second, individuals must be given an opportunity to partake in change-oriented initiatives, not philanthropy-oriented tasks that only aim to raise monetary support for a cause. The students in Fuller et al.'s study, for instance, worked closely with urban youth in a sport-based development program. Third, people need to engage in difficult dialogues and critically reflect on their experiences.

Attitudes Toward the Role of Sport. How a person views sport and the role it can play in promoting social change can also influence one's attitudes and behaviors toward change. Taylor (2015), for example, contends the purpose of sport is to give participants "an opportunity to learn, enjoy the camaraderie of competition, and show respect for another human being." Viewing sport in this way motivates Taylor to vocally challenge norms and practices within sport that do not promote a culture of inclusion and respect for all.

Similar to Taylor, a number of nonprofit organizations believe sport is an effective way to help facilitate desired social outcomes (see in this issue Welty Peachey, 2015; see also Sherry, Schulenkorf, \& Chalip, 2015). Street Soccer USA, for example is a nonprofit organization that uses sport to foster camaraderie, community, and confidence, which helps empower homeless individuals to find greater success and peace in their lives. The purpose of sport within this context is not to dominate the opponent or win at all costs. Rather, sport is viewed as an inclusive and safe environment where diverse individuals can come together, learn from each other, and work toward common goals. Volunteering in such a setting allowed participants in Fuller et al.'s (2015) study to recognize the role of sport in building relationships and helping communities. In particular, Julian-a student-athlete who now plays professional football—realized how sport gave him a way to connect with young people and make a difference in their lives.

Finally, while there is considerable evidence that social change behaviors generate desired outcomes for those in the target population, the papers included in this special issue highlight the effects these behaviors have on the change agent. Through his advocacy work, for example, Taylor (2015) realized being an ally for a marginalized group is not merely an identity one holds; instead, allyship is a way of life that motivates one to tirelessly work toward ending all forms of oppression. Fuller and his colleagues (2015) also observed increased social justice intentions and behaviors among students who engaged in social change activities during a sport-based service learning course. In addition, students expressed an increased awareness of social injustice, understanding of their privileged social status, sense of empowerment, and developed greater cultural competence-a skill that is vital to effective management in a diverse workforce (see Bennett, 2014).

\section{Conclusions}

The purpose of this special issue was to advance theory and research on social change within intercollegiate sport. As demonstrated through the multilevel model, this objective was met. The papers address the antecedents and outcomes of social change at the macro, meso, and microlevel of analysis. In addition, I also discussed ways in which factors at various levels work together or interact 
to affect attitudes and behaviors related to change. While the model and articles presented in this special issue are not exhaustive, the macro, meso, and microlevel factors can inform current and future research on social change in intercollegiate sport. As such, researchers are encouraged to use the model to help stimulate new research questions and investigations on the causes and outcomes associated with social change initiatives.

From a practical perspective, the articles in this special issue illustrate how change is possible in and through intercollegiate sport. Recent events suggest student-athletes are becoming more aware of social injustices within the realm of sport and in the broader society, and they want to play an active role in working toward social change. Indeed, while some athletes are still hesitant to speak out due to persistent social norms within sport, it appears the culture of silence is gradually coming to an end. As such, let us continue this momentum toward change, and as Welty Peachey (2015) notes in his concluding comments, "... consider how we can contribute to a radically different conversation and view of intercollegiate sport, and how it and its agents can be activists and agitators for social change" (p.103).

Researchers, administrators, coaches, and advocates can draw from the articles in this special issue to understand how to foster social change in their respective domains. First, we must articulate the positive role sport can play in affecting change. This involves exhibiting attitudes and behaviors that emphasize sport values of respect, fairness, inclusivity, and teamwork. Second, we need to create perspective-altering experiences that not only allow people to understand the effects of social injustice, but also equips them with the skills, abilities, and resources to generate positive change in their communities. We can create these opportunities by developing sport-based service learning courses, establishing change-oriented service projects outside the classroom setting, or by allowing students to take an active role in research projects that focus on social change.

Third, developing mutually beneficial partnerships assists in our efforts to tackle social issues and broadens our perspective on what changes need to take place and how to achieve our collective goals. Over the past 10 years, for example, the NCAA Office of Inclusion has worked with activists and researchers on how to provide opportunities for individuals with disabilities. These discussions and collaborative efforts paved the way for the East Coast Athletic Conference to offer varsity athletics for student-athletes with a disability (Hums \& Wolff, 2015). Finally, in our pursuit of social change, we must remember to use compelling narratives that will resonate with a broad audience. The narratives may draw from the personal stories of change agents, moral arguments emphasizing the legitimacy of prosocial behaviors, scholarly research highlighting the effectiveness of sport-for-development programs, or empirical data that illustrates the personal and organizational benefits associated with social change.

To conclude, I hope this multilevel model inspires researchers and practitioners alike to continue to explore ways we can create social change in intercollegiate sport. While there are certainly challenges to overcome, the papers included in this special issue demonstrate that change is possible. As sport management scholars and practitioners, we must recognize our ability to influence social issues and unreservedly embrace the opportunity to educate and empower future change advocates. 


\section{References}

Agyemang, K., Singer, J.N., \& DeLorme, J. (2010). An exploratory study of black male college athletes' perceptions of race and athlete activism. International Review for the Sociology of Sport, 45, 419-435. doi:10.1177/1012690210374691

Andrassy, E.J., \& Bruening, J.E. (2011). From rhetoric to reality: NCAA division I athletic department mission statements and student-athlete community service efforts. Journal of Issues in Intercollegiate Athletics, 4, 271-288.

Bandura, A. (1986). Social foundations for thought and action: A social cognitive theory. Englewood Cliffs, NJ: Prentice-Hall.

Brand, M. (2005). NCAA correctly positioned as a catalyst for social change. Retrieved from http:// fs.ncaa.org/Docs/NCAANewsArchive/2005/Editorial/ncaa+correctly+positioned+as+a +catalyst+for+social+change+-+10-24-05+ncaa+news.html.

Bennett, J.M. (2014). Intercultural competence: Vital perspectives for diversity and inclusion. In B.M. Ferdman \& B.R. Deane (Eds.), Diversity at work: The practice of inclusion (pp. 55-90). San Francisco, CA: Jossey-Bass.

Bruening, J., \& Dixon, M.A. (2008). Situating work-family negotiations within a life course perspective: Insights on the gendered experiences of NCAA Division I head coaching mothers. Sex Roles, 58, 10-23. doi:10.1007/s11199-007-9350-x

Burnett, C. (2006). Building social capital through an 'active community club'. International Review for the Sociology of Sport, 41, 283-294. doi:10.1177/1012690207078381

Burton, L.J. (2014).Underrepresentation of women in sport leadership: A review of research. Sport Management Review, 18, 155-165.

Burton, L., \& Welty Peachey, J. (2014). Ethical leadership in intercollegiate sport: Challenges, opportunities, future directions. Journal of Intercollegiate Sport, 7, 1-10. doi:10.1123/jis.2014-0100

Coakley, J. (2009). Sports in society: Issues and controversies (10th ed.). New York: McGraw Hill.

Cunningham, G.B. (2008). Creating and sustaining gender diversity in sport organizations. Sex Roles, 58, 136-145. doi:10.1007/s11199-007-9312-3

Cunningham, G.B. (2010). Understanding the under-representation of African American coaches: A multilevel perspective. Sport Management Review, 13, 395-406. doi:10.1016/j.smr.2009.07.006

Cunningham, G.B. (2011a). The LGBT advantage: Examining the relationship among sexual orientation diversity, diversity strategy, and performance. Sport Management Review, 14, 453-461. doi:10.1016/j.smr.2010.11.003

Cunningham, G.B. (2011b). Creative work environments in sport organizations: The influence of sexual orientation diversity and commitment to diversity. Journal of Homosexuality, 58, 1041-1057. PubMed doi:10.1080/00918369.2011.598413

Cunningham, G. B. (2012). A multilevel model for understanding the experiences of LGBT sport individuals. Journal for the Study of Sports and Athletes in Education, 6, 5-20.

Cunningham, G.B. (2014). Interdependence, mutuality, and collective action in sport. Journal of Sport Management, 28, 1-7. doi:10.1123/jsm.2013-0152

Cunningham, G. (2015). LGBT inclusive athletic departments as agents of social change. Journal of Intercollegiate Sport, 8, 43-56.

Edwards, M.B. (2015). The role of sport in community capacity building: An examination of sport for development research and practice. Sport Management Review, 18, 6-19. doi:10.1016/j.smr.2013.08.008

Fink, J.S. (2014). Female athletes, women's sport, and the sport media commercial complex: Have we really "come a long way, baby"? Sport Management Review.

Fuller, R., Evanovich, J., Bruening, J., Welty Peachey, J., Coble, C., Percy, V., Maladouangdock, J., \& Corral, M. (2015). The impact of a sport-based service learning course on participants' attitudes, intentions and actions towards social change. Journal of Intercollegiate Sport, 8, 14-36. 
Gray, B. (1989). Collaborating: Finding common ground for multi-party problems. San Francisco, CA: Jossey-Bass.

Hayles, V.R. (2014). Communicating about diversity and inclusion. In B.M. Ferdman \& B.R. Deane (Eds.), Diversity at work: The practice of inclusion (pp. 55-90). San Francisco, CA: Jossey-Bass.

Hayles, V.R., \& Russell, A.M. (1997). The diversity directive: Why some initiatives fail and what to do about it. New York: McGraw-Hill.

Hudson, L.J. (2009). The Enabling State: Collaborating for Success. Retrieved from http:// www.mbsportal.bl.uk/taster/subjareas/strategy/fco/102378enabling09.pdf

Hums, M., \& Wolff, E. (2015). Research and Advocacy in Disability Sport and Sport and Human Rights: The Journey Along the Road to Scholar-Advocacy. Sport and Entertainment Review, 1, 27-32.

Jackson, D. (2015). W.H. takes anti-violence campaign to NCAA tournaments. Retrieved from http://www.usatoday.com/story/theoval/2015/03/18/obama-its-on-us-ncaabasketball-tournaments-espn/24965677/

Kozlowski, S.W.J., \& Klein, K.J. (2000). A multilevel approach to theory and research in organizations: Contextual, temporal, and emergent processes. In K.J. Klein \& S.W.J. Kozlowski (Eds.), Multilevel theory, research, and methods in organizations: Foundations, extensions, and new directions (pp. 3-90). San Francisco: Jossey-Bass.

Maine, D. (2015). Duke athletes star in powerful \#youdontsay campaign. Retrieved from http://espn.go.com/espnw/athletes-life/blog/post/17380/duke-athletes-star-powerfulyoudontsay-campaign

Martin, N., Ross, S., \& Irwin, R. (2015). Utilizing community-based social marketing in a recycling intervention with tailgaters. Journal of Intercollegiate Sport, 8, 57-81.

Melton, E.N., \& Cunningham, G.B. (2012). When identities collide: Exploring multiple minority stress and resilience among college athletes. Journal for the Study of Sports and Athletics in Education, 6, 45-66. doi:10.1179/ssa.2012.6.1.45

Melton, E.N., \& Cunningham, G.B. (2014). Who are the champions? Using a multilevel model to examine perceptions of employee support for LGBT-inclusion in sport organizations. Journal of Sport Management, 28, 189-206. doi:10.1123/jsm.20120086

Misener, L., \& Darcy, S. (2014). Managing disability sport: From athletes with disabilities to inclusive organisational perspectives. Sport Management Review, 17, 1-7. doi:10.1016/j. smr.2013.12.003

Meyer, J.W., \& Rowan, B. (1977). Institutionalized organizations: Formal structure as myth and ceremony. American Journal of Sociology, 83, 340-363. doi:10.1086/226550

ESPN. (2015). Irish wear 'I Can't Breathe' shirts. Retrieved from http://espn.go.com/womens-college-basketball/story/_id/12023106/notre-dame-women-wear-breathe-t-shirts

NCAA. (2007). NCAA CHAMPS/Life Skills Program. Retrieved from http://www.ncaapublications.com/productdownloads/LS07.pdf

Sartore, M.L., \& Cunningham, G.B. (2010). The lesbian label as a component of women's stigmatization in sport organizations: A comparison of two health and kinesiology departments. Journal of Sport Management, 24, 481-501.

Shaw, S., \& Frisby, W. (2006). Can gender equity be more equitable?: Promoting and alternative frame for sport management research, education, and practice. Journal of Sport Management, 20, 483-509.

Sherry, E., Schulenkorf, N., \& Chalip, L. (2015). Managing sport for social change: The state of play. Sport Management Review, 18, 1-5. doi:10.1016/j.smr.2014.12.001

Singer, J.N. (2005). Understanding racism through the eyes of African American male studentathletes. Race, Ethnicity and Education, 8, 365-386. doi:10.1080/13613320500323963

Staurowsky, E. (2014). College athletes' rights in the age of the super conference: The case of the All Players United Campaign. Journal of Intercollegiate Sport, 7, 11-34. doi:10.1123/jis.2013-0052 
Taylor, H. (2015). Activating change through allyship. Journal of Intercollegiate Sport, 8, $37-42$.

Walker, N. A., \& Melton, E. N. (2015). Creating opportunities for social change in women's sport through academic and industry collaboration: An interview with Kate Fagan. Journal of Intercollegiate Sport, 8, 82-95.

Walker, N.A., \& Melton, E.N. (in press).The triple threat: Examining the intersection of gender, race, and sexual orientation in sport organizations. Journal of Sport Management.

Walker, N., \& Sartore-Baldwin, M. (2013). Hegemonic masculinity and the institutionalized bias toward women in men's collegiate basketball: What do men think? Journal of Sport Management, 27, 303-315.

Washington, M., \& Patterson, K.D.W. (2011). Hostile takeover or joint venture: Connections between institutional theory and sport management research. Sport Management Review, 14, 1-12. doi:10.1016/j.smr.2010.06.003

Welty Peachey, J. (2015). Creating social change in and through intercollegiate sport: State of the field, challenges, and future directions. Journal of Intercollegiate Sport, 8, 96-105. 